\title{
Isolated splenic vein thrombosis as a complication of abdominal trauma in a 3-month-old girl
}

\author{
Izolowana zakrzepica żyły śledzionowej jako powikłanie urazu brzucha u 3-miesięcznej dziewczynki
}

1 Department of Paediatrics and Nephrology, Medical University of Warsaw, Warsaw, Poland

2 Department of Paediatric Radiology, Medical University of Warsaw, Warsaw, Poland

Correspondence: Agnieszka Szmigielska, Department of Paediatrics and Nephrology, Medical University of Warsaw, Żwirki i Wigury 63A, 02-091 Warsaw, Poland,

tel.: +48 22317 96 56, fax: +48 22317 99 54, e-mail: agnieszka.szmigielska@wum.edu.pl

Abstract Falls from heights and traffic accidents are the most common causes of splenic damage. Abdominal trauma can cause splenic rupture or splenic vein thrombosis. About $11-55 \%$ of children with splenic vein thrombosis develop collateral circulation, leading to gastric and/or oesophageal varicose veins. Venous thrombosis in children can be also caused by congenital factors associated with coagulation disorders. The paper describes a case of a 3-month-old girl who developed isolated splenic vein thrombosis after a fall from height. Laboratory and genetic findings excluded thrombophilia. A 3-month anticoagulant treatment was administered. Gradual reduction in splenic size and the development of collateral circulation were observed in subsequent ultrasound scans. The girl remains under the care of a surgical clinic. The presented case of an infant with splenic vein thrombosis draws attention to possible complications of abdominal trauma after a fall from height.

Keywords: splenic vein thrombosis, abdominal trauma, thrombotic disorders, infant, children

Streszczenie Przyczyną uszkodzeń śledziony są najczęściej upadki z wysokości lub wypadki komunikacyjne. Uraz jamy brzusznej może spowodować pęknięcie śledziony lub zakrzepicę żyły śledzionowej. U 11-55\% dzieci z zakrzepicą żył śledzionowej obserwuje się rozwój krążenia obocznego, które prowadzi do powstania żylaków żołądka i/lub przełyku. Zakrzepica żylna u dzieci może być również spowodowana czynnikami wrodzonymi związanymi z zaburzeniami w układzie krzepnięcia. W pracy opisano przypadek 3-miesięcznej dziewczynki, u której doszło do izolowanej zakrzepicy żyły śledzionowej po upadku z wysokości. $\mathrm{Na}$ podstawie badań laboratoryjnych i genetycznych wykluczono trombofilię. Zastosowano trwające 3 miesiące leczenie przeciwzakrzepowe. W kolejnych badaniach ultrasonograficznych obserwowano stopniowe zmniejszanie się wymiarów śledziony i rozwój krążenia obocznego. Dziewczynka pozostaje pod opieką poradni chirurgicznej. Prezentowany przypadek niemowlęcia z zakrzepicą żyły śledzionowej zwraca uwagę na możliwe powikłania urazu brzucha po upadku z wysokości.

Słowa kluczowe: zakrzepica żyły śledzionowej, uraz brzucha, choroby zakrzepowe, niemowlę, dzieci 


\section{INTRODUCTION}

A ccording to the Centers for Disease Control and Prevention (CDC), the estimated mortality of United States children aged 1-4 years and 5-18 years was $23.3 / 100,000$ and $13.4 / 100,000$, respectively, in 2018. Accidents and unintentional injuries are the most common causes of mortality in children aged 1-14 years. Other, less common causes include congenital and genetic defects, cancer and suicide. The highest mortality, i.e. 5.79/1,000 live births, is reported for children under one year of age (United States, 2017) $)^{(1)}$. Congenital defects, prematurity-related complications, maternal diseases, sudden infant death syndrome (SIDS), and injuries are the most common causes of infant mortality. Children with cardiovascular and respiratory diseases, systemic infections and bleedings are at a higher risk of death. The number of injuries and accidents in children is constantly growing with the development of civilisation. Abdominal injuries occur in about $25 \%$ of children after serious accidents ${ }^{(2)}$. Falls from height (dropping the child or falling out of the crib) are the most common cause of unintentional injuries among infants. In the case of blunt abdominal trauma, splenic complications, such as splenic rupture, are most common $^{(3)}$.

Splenic vein thrombosis (SVT) is diagnosed mainly in adults $^{(4)}$. Physical examination or diagnostic imaging may reveal splenomegaly in SVT. It may be accompanied by thrombocytopenia, pancytopenia and abdominal pain. Upper gastrointestinal bleeding caused by gastric varices may be the first symptom. Compared to patients with portal hypertension, the course of the disease is asymptomatic with normal liver function in most SVT patients. Asymptomatic patients do not require treatment, whereas splenectomy is recommended in symptomatic patients ${ }^{(5)}$.

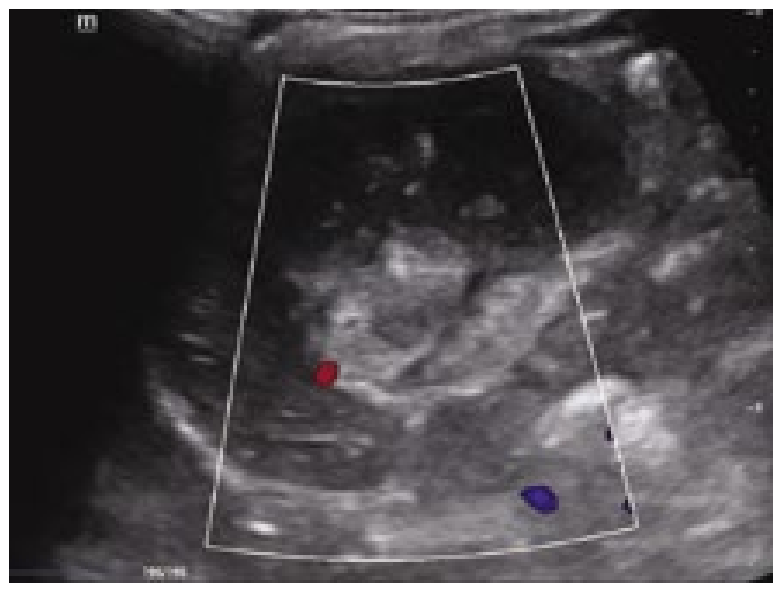

Fig. 1. Abdominal ultrasound with Doppler function. Oedematous, hypoechoic spleen (length $66 \mathrm{~mm}$ ) with an oedema-

\section{CASE REPORT}

A girl from first pregnancy and first delivery (vaginal), full-term, with birth weight of 3,270 g and an Apgar score of 10 . The child had no medical history, was vaccinated according to the vaccination schedule, breastfed on demand, received vitamin D3 supplementation. At the age of 3 months, she was admitted to hospital with suspicion of urinary tract infection. She developed a fever of up to $38.9^{\circ} \mathrm{C}$ at home, which persisted for 3 days, for no apparent reason. Roseola infantum was initially suspected, but after 3 days of observation, a general urine test was performed due to persistent fever and the absence of rash. Urinalysis revealed leukocyturia (20-30 in the field of view). Furthermore, it was found that the girl fell from a bed, with bed to floor height of about $40-50 \mathrm{~cm}$ ). After the fall, the parents observed no behavioural disturbances or vomiting, and they did not report that to a doctor. Family history was of no clinical importance. Physical examination on admission showed fever of $38.9^{\circ} \mathrm{C}$, tachycardia up to $134 / \mathrm{min}$; normal blood saturation and pressure. The child showed no obvious signs of infection, with palpable liver up to $2 \mathrm{~cm}$ under the right costal arch and spleen up to $2 \mathrm{~cm}$ under the left costal arch. Laboratory workup showed increased inflammatory markers: C-reactive protein (CRP) $7.3 \mathrm{mg} / \mathrm{dL}$ (reference $<0.5 \mathrm{mg} / \mathrm{dL}$ ) and leukocytosis $25.77 \times 10^{3} / \mu \mathrm{L}$. Red blood cell and platelet counts, the parameters of kidney and liver function, as well as urinalysis were normal. She had been put on cefuroxime before the urine culture was verified. The fever resolved on day 2 of treatment, and the urine culture was sterile. Abdominal ultrasound was performed and showed splenic vein thrombosis and splenomegaly up to $66 \mathrm{~mm}$ in the long axis with an oedematous hyperechoic capsule (Fig. 1). Splenic arterial flow was visible, while the venous flow was difficult to assess (Fig. 2). Due to the confirmed thrombosis, a coagulation test was performed, which confirmed the signs of active intravascular coagulation: D-dimers 5,466.42 $\mu \mathrm{g} / \mathrm{L}$ (reference: 190-700 $\mu \mathrm{g} / \mathrm{L}$ ), fibrinogen $<0.35 \mathrm{~g} / \mathrm{L}$ (reference: $1.8-3.8 \mathrm{~g} / \mathrm{L}$ ).

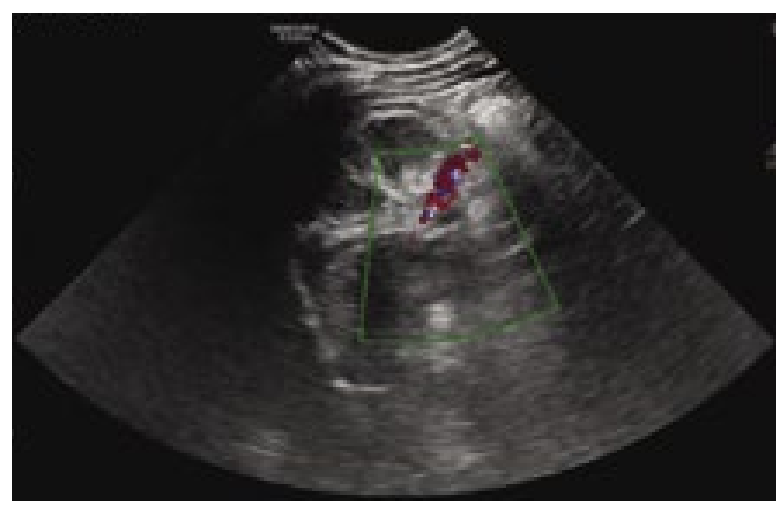

Fig. 2. Abdominal ultrasound with Doppler function. Splenomegaly with trace flow in the splenic vein, possible partial vein recanalisation 


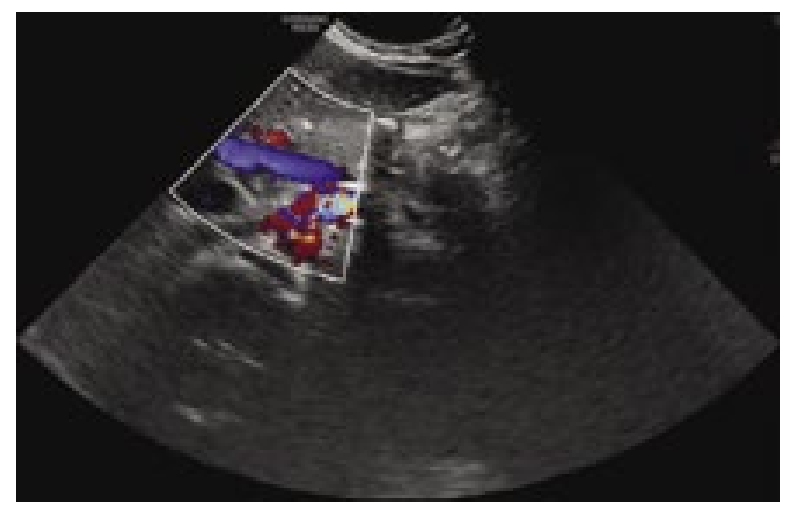

Fig. 3. Abdominal ultrasound with Doppler function after 3 months of treatment. Splenic vein thrombosis, collateral vessels in the hilum

Nadroparin was used for 3 months. After the end of the therapy, the level of protein $\mathrm{S}$ was assessed, obtaining the result of $70.5 \%$ (reference: $59-118 \%$ ), protein C - 89.1\% (reference: $50-125 \%$ ) and antithrombin III (AT III) 85\% (reference: 75-125\%). Genetic testing excluded factor V Leiden mutation (FVLM). A follow-up ultrasound scan performed after 3 months showed a $42 \mathrm{~mm}$-long hypoechoic spleen with visible flow in the portal vein and in the very narrow distal section of the splenic vein (Fig. 3). Gradual reduction in the splenic size and collateral circulation were observed in subsequent ultrasound scans. Despite normal psychomotor development, the girl remains under the care of a surgical clinic due to the possibility of complications.

\section{DISCUSSION}

The clinical picture of visceral vein thrombosis is associated with the location of vascular obstruction. Thrombosis can affect the inferior vena cava and/or the hepatic veins (Budd-Chiari syndrome), but also the portal, splenic, superior and inferior mesenteric veins. Isolated splenic vein thrombosis is a rare clinical complication. Splenomegaly and the presence of varicose veins in a person with normal liver function are referred to as left-sided portal hypertension. Diagnostic difficulties in SVT are related to the frequent asymptomatic course of the disease $\mathrm{e}^{(6)}$. The absence of clinical symptoms delays the diagnosis. Diagnosis is initiated only after the patient has developed clinical symptoms, such as abdominal pain or upper gastrointestinal bleeding, or when splenomegaly is diagnosed. Since the symptoms of SVT are non-specific, the diagnosis is sometimes based on ultrasound, computed tomography or magnetic resonance imaging performed for other reasons ${ }^{(7)}$.

Risk factors for visceral vein thrombosis can be either congenital or acquired. Congenital factors include disorders in the coagulation system that promote thrombophilia, such as factor V Leiden mutations, mutations in the prothrombin gene, MTHFR (methylenetetrahydrofolate reductase) mutations, and protein $\mathrm{C}, \mathrm{S}$ and AT III deficiencies. FVLM is the most common coagulation disorder ${ }^{(8)}$. The risk of thrombosis increases 5-8 times in patients with heterozygous FVLM and 50-80 times in those with homozygous FVLM ${ }^{(9)}$. Prothrombin gene mutations increase the risk of thrombosis 2-4 times in heterozygotes and 10 times in homozygotes. However, this mutation was not found in the group of patients with SVT in many clinical studies $^{(10)}$. MTHFR mutations may contribute to the development of hyperhomocysteinemia (homozygotes) and vascular damage. Bhattacharyya et al., found MTHFR mutations in $21 \%$ of patients (heterozygotes) with portal vein thrombosis $^{(11)}$. Protein C, S and AT III deficiency is a risk factor for thrombosis. However, it should be remembered that since these are proteins produced in the liver, their levels may be reduced in hepatic diseases.

Acquired risk factors for SVT include pancreatic diseases (acute and chronic inflammation, cancer), myeloproliferative syndromes, injuries, surgeries, pregnancy, antiphospholipid syndrome and infections. The splenic vein runs near the pancreas, which makes pancreatic diseases (acute or chronic pancreatitis and pancreatic cancer) the most common causes of thrombosis. Intravascular coagulation is promoted by inflammation near the vein, pressure on the vessel caused by oedema, cyst or enlarged lymph nodes ${ }^{(12)}$. In diagnostic imaging, the incidence of SVT in patients with pancreatic diseases is 5-22\%. In newborns, the development of SVT is promoted by catheterisation of the umbilical vessels. Renal cysts compressing the splenic vein may be a rare cause of SVT. However, it is not always possible to identify the factors that lead to thrombosis. Dutta et al. has shown congenital coagulation disorders in $25 \%$ and acquired factors promoting thrombosis in $45 \%$ of patients with visceral vein thrombosis. The aetiology of thrombosis remains unknown in the remaining patients ${ }^{(13)}$. Determining the causes of thrombosis may be useful in the context of appropriate treatment and further prevention. Conservative therapy is used in approximately $95 \%$ of cases. The decision to initiate anticoagulation therapy should be individualised, depending on the patient's clinical condition, symptoms and the cause of thrombosis. Low molecular weight heparin is the treatment of choice. The therapy should be continued for at least 3 months. Splenectomy should be performed in symptomatic patients ${ }^{(14)}$.

Our patient was admitted to the hospital due to fever and suspected urinary tract infection. This diagnosis was made on the basis of leukocyturia, which was probably a consequence of incorrect urine sampling. Fever of unknown aetiology requires additional tests and extensive diagnosis. In the presented case, the diagnosis of SVT was based on abdominal ultrasound with Doppler option. SVT is most often associated with pancreatic diseases. In the described case, infection was excluded as a secondary cause of thrombosis. The girl was also diagnosed for congenital thrombophilia. FVLM was excluded; C, S and AT III 
levels were normal. Isolated SVT was probably caused by injury. Anticoagulation treatment failed to achieve total vein recanalisation. Subsequent ultrasound scans showed developing collateral circulation, which leads to gastric and/or oesophageal varicose veins in $11-55 \%$ of children with SVT. Currently, the girl requires continuous surgical care and regular ultrasound follow-up to identify potential complications.

\section{CONCLUSIONS}

1. Abdominal trauma may cause splenic vein thrombosis.

2. Low molecular weight heparin is the treatment of choice for patients with splenic vein thrombosis and should be used for at least 3 months.

3. Patients diagnosed with splenic vein thrombosis should be monitored for collateral circulation that may lead to gastric and/or oesophageal varices.

\section{Conflict of interest}

The authors do not declare any financial or personal links to other persons or organisations that could adversely affect the content of this publication or claim rights thereto.

\section{References}

1. Centers for Disease Control and Prevention. Available from: www.cdc.gov/nchs/fastats/child-health.htm.

2. Lynch T, Kilgar J, Al Shibli A: Pediatric abdominal trauma. Curr Pediatr Rev 2018; 14: 59-63.

3. Łukaszewicz J, Czarnowicz R, Chojnacki W: Urazy okolicy brzucha u dzieci. Rocznik Dziecięcej Chirurgii Urazowej 1999; 26: 40-43.

4. Hidajat N, Stobbe H, Griesshaber V et al.: Portal vein thrombosis: etiology, diagnostic strategy, therapy and management. Vasa 2005; 34: 81-92.

5. Köklü S, Coban S, Yüksel O et al.: Left-sided portal hypertension. Dig Dis Sci 2007; 52: 1141-1149.

6. Nadkarni NA, Khanna S, Vege SS: Splanchnic venous thrombosis and pancreatitis. Pancreas 2013; 42: 924-931.

7. Chen $\mathrm{BC}$, Wang $\mathrm{HH}$, Lin $\mathrm{YC}$ et al.: Isolated gastric variceal bleeding caused by splenic lymphoma-associated splenic vein occlusion. World J Gastroenterol 2013; 19: 6939-6942.

8. Lucotte G, Mercier G: Population genetics of factor V Leiden in Europe. Blood Cells Mol Dis 2001; 27: 362-367.

9. Bayraktar Y, Harmanci O: Etiology and consequences of thrombosis in abdominal vessels. World J Gastroenterol 2006; 12: $1165-1174$.

10. Koshy A, Jeyakumari M: Prothrombin G20210A gene variant is not associated with idiopathic portal vein thrombosis in an area endemic for portal vein thrombosis. Ann Hematol 2006; 85: 126-128.

11. Bhattacharyya $M$, Makharia G, Kannan $M$ et al.: Inherited prothrombic defects in Budd-Chiari syndrome and portal vein thrombosis: a study from North India. Am J Clin Pathol 2004; 121: 844-847.

12. Matei D, Brenner B, Marder VJ: Acquired thrombophilic syndromes. Blood Rev 2001; 15: 31-48.

13. Dutta AK, Chacko A, George B et al.: Risk factors of thrombosis in abdominal veins. World J Gastroenterol 2008; 14: 4518-4522.

14. Ageno W, Beyer-Westendrof J, Garcia DA et al.: Guidance for the management of venous thrombosis in unusual sites. J Thromb Thrombolysis 2016; 41: 129-143. 